\title{
Ipads versus Books
}

\author{
Yvonne Shirley \\ Department of Early Childhood Education, Missouri State University, Springfield, USA \\ Email: yvonne85@live.missouristate.edu
}

How to cite this paper: Shirley, Y. (2018). Ipads versus Books. Creative Education, 9, 115-139.

https://doi.org/10.4236/ce.2018.91010

Received: November 14, 2017

Accepted: January 28, 2018

Published: January 31, 2018

Copyright $\odot 2018$ by author and Scientific Research Publishing Inc. This work is licensed under the Creative Commons Attribution-NonCommercial International License (CC BY-NC 4.0).

http://creativecommons.org/licenses/by-nc/4.0/

\begin{abstract}
During the past few years, technology such as iPads has been a growing trend in classrooms. Students are slowly being drawn away from text books and introduced to digital books on iPads. This study seeks to gain insights into the effectiveness of the implementation of technology in early childhood classrooms. To examine the effectiveness of using iPads for reading, this study addresses the following question: Do children comprehend more when reading from iPads? Ten kindergarten students participated in this study. Their reading comprehension scores when reading from iPads and books were collected within a two-week interval and then compared. After reading stories from iPads and books, students were asked comprehension questions from the DRA and their scores were recorded for each section of comprehension skills which included: previewing, retelling of events, character details, retelling using vocabulary, retelling with teacher's support, reflections, and making connections. The data showed that nine out of ten students scored higher in reading comprehension when reading from iPads, and one student scored the same on both. This study suggests that more research on effective, appropriate, and intentional teaching with iPads and other technology in classrooms is needed to further examine the benefits and downfalls of using such devices in the field of education.
\end{abstract}

\section{Keywords}

Technology, iPads, Reading Comprehension, DRAs, Action Research

\section{Introduction}

Technology in early childhood classrooms has been a rising topic in education. While some believe that it enhances learning, others do not think it should be used in place of conventional methods that they been accustomed to for many years. Labbo (1996) argues that to describe and explain young children's literacy development completely, the definition of reading and writing must be broa- 
dened to include multimedia and computer based print. Goodman (1986) described the roots of literacy as the process of making meaning through reading, writing, and communicating. "Using iPad applications to read with or communicate may facilitate the emergence of the roots of literacy in a digital environment similar to those that adults frequently use and within which children will be expected to be able to use more conventionally as they become older" (Goodman, 1986: p. 2).

In this action research study, I compared reading comprehension scores of my kindergarten students using iPads and books, I then made comparisons of my students' reading comprehension when reading a story from conventional books compared to reading a story from iPads. I tested the students' ability to comprehend the material they read from both sources and compared which rates the highest level of reading comprehension by using the Developmental Reading Assessments (DRAs) from books to compare to the stories from the iPads.

\section{Rationale for the Study}

Given the importance of technology in this day and time and the rise of technology in the classroom, it is important to pursue this study to find out the effectiveness of the use of technology in early childhood classrooms. In a new study by Subramanian (2012), it was found that iPads in the classroom do boost students' grades. Subramanian said that "educators in Auburn, Maine began instructing 266 kindergarteners using the iPad 2 this fall, and those who used the tablet scored higher on literacy tests and were more enthused about learning." After reviewing this article, I was even more certain that this was what I wanted to do my article on.

Ipads are expensive and with all the money being invested into technology in the classroom, it is necessary to find out how students are benefitting from the technology. Leonard (2013) says "In September, the Los Angeles Unified School District began carrying out a $\$ 50$ million plan to equip 30,000 students in 47 schools from kindergarten through 12th grade with an iPad." In my experience as a teacher, when students are asked to get a book and read to themselves, they do not stay focused or engaged for a very long period. I noticed the duration of their interest in books is somewhere between five and ten minutes. When they read a story from the iPad, they seem to be more focused and excited about reading. They stay focused for 30 minutes or more. During listening comprehension tests, which are given after reading from books, students were not able to recall as much information as they did when reading from applications on the iPads.

This study provided information as to whether these students learned more effectively from the use of technology or if prior methods of conventional reading were just as effective. I believe this study will be very useful to the department of education because it will prove the effectiveness of iPads in the area of reading comprehension and literacy in early childhood classrooms. 
My students seemed to be more engaged and have made many improvements in their reading skills with the use of iPads and the SMART board in our classroom. The students have advanced in reading levels very quickly and have proved that they understand the content of the story by simple retelling activities. There are applications that can be used that allow students to read digital stories and then take comprehension tests afterward to determine how much of the stories they are able to recall. One application is called Razkids (2015). They can earn points to build rocket ships which provide motivation to read more and comprehend what is being read.

When referring back to the articles from Dorner (2002), Robinson \& Pierson (2005), Sadik (2008), and Willis (2014), I can recall the benefits of technology opposed to the drawbacks. The benefits are that technology is very useful to both students and teachers because it enhances the relationships between them and provides more convenient methods of educating students (Sadik, 2008). Technology, such as an iPad, offers a more entertaining and engaging way to interact in early childhood classrooms due to the many different applications that can be used to introduce stories and help students understand the meaning the stories are trying to convey. This, in turn, will hold their interest for a longer period of time opposed to books (Sadik, 2008). Hutchison, Beschorner, \& Schmidt-Crawford (2012) say that using iPads for literacy instruction supported student learning and highly engaged students to demonstrate unique and creative ways of responding to text using a technology tool. Willis (2014) says that using technology tends to be more interesting and intriguing to students and teachers alike and there are many advantages that can be found in its use in the classroom.

The drawbacks include the fact that technology is not always available to students outside of the classroom and sometimes there are problems with glitches in technical devices Dorner (2002). Robinson \& Pierson (2005) say another drawback is that some teachers may not feel confident enough to teach with technology because they are not knowledgeable enough to implement it in the classroom and have a fear of what they are not familiar with. Willis (2014) states that some cons of using iPads are that they can easily be being broken by students, can become unnecessary distractions in the classroom, their battery life is short, and there are issues of online safety and security. Despite the few shortcomings that are found when using iPads, studies show that they have been proven to increase students' reading comprehension, so I believe the benefits will be greater than the shortcomings.

\section{Purpose of the Study}

The purpose of this action research study was to compare the reading comprehension scores of kindergarten students when reading from iPads compared to books. This study was done to determine whether students comprehended more of what they read when using iPads compared to books. The method of action research study was done by assessing students using the comprehension section 
of a DRA to determine which method would be the most effective when reading. I compared the reading comprehension test scores from the DRAs in order to determine if they scored higher in reading comprehension when reading from iPads compared to books.

\section{Research Questions}

The main research question is: What is the impact of the use of iPad technology integration on early reading skills, as measured with the DRAs'?

I divided my main question into two sub-questions:

1) In what ways did iPads affect childrens' recall scores compared to reading from books?

2) In what ways did iPads affect childrens' comprehension scores compared to reading from books?

\section{Research Hypothesis}

I hypothesized that there would be a significant difference between the students' reading comprehension scores when they were using iPads compared to reading from books. I believed this to be true because students seemed much more engaged when using iPads rather than reading from books. If students are engaged in their learning, they are more likely to comprehend what they are learning.

Children seemed to pay more attention when something new was presented to them and it seemed like a change in methods was very rewarding in this situation. I believe that iPads had the ability to hold the interests of students far better than books.

I hypothesized that there would be a change in reading comprehension when reading from iPads compared to reading from books due to the excitement of reading from the iPads and the connection between engagement and comprehension.

I predicted that when students read from iPads, there would be more correct answers because when they become more engaged in the stories, they tend to remember them better. If they are bored with the readings, they tend to skip around and miss a lot of information that the stories provide.

I thought there would be a larger number of students who had higher comprehension scores when reading from iPads opposed to those reading from books due to higher interest placed on modern technology compared to the old-school method of reading from books.

\section{Research Design}

For the research design, I used action research study to determine how technology affected learning in early childhood classrooms. During the first week, I let the students read stories using the book of their choice according to their reading level. I then assessed the students using DRAs. On the following week, I repeated the process but let the students read a story of their choice based on their 
reading level from iPads using Raz-Kids. After they read the story, I assessed the students using the comprehension section of a DRA. The purpose of using the comprehension portion of the DRA was to see if students achieved a higher score while reading from iPads compared to books. These tests should prove my theory of the use of iPads being a more effective way of teaching literacy.

\section{Significance of Study}

I believe the significance of this study on the use of iPads for literacy purposes in the early childhood classroom, proved that technology could make a significant difference in the way students learned and retained information they received. I think this study will be valuable when choosing whether or not it is good to incorporate iPads in the classroom by proving it can have a very big impact on the way students learn. This study will not only benefit the development and education of our students but will also be of value to teachers and parents as well. Technology will be able to benefit education as a whole. The knowledge of this research will be shared at conferences, discussed at professional meetings, and sent out in newsletters to be shared with parents and to whomever else it may concern.

\section{Assumptions}

1) The students' ability to use the iPads.

2) The difficulty in implementing this type of technology in early childhood classrooms.

3) The expense that is involved in incorporating technology in early childhood classrooms.

4) How computer literate the teaching staff is and how well they accept the change.

5) Whether or not this technology is offered to the child outside the classroom.

\section{Limitations}

1) I believe there will be some limitations with students reading from iPads because they may not understand how to use the iPads.

2) I think other limitations could be the possibility of technical difficulties or glitches when using the iPads.

3) Students may be more interested or connected to one story based on many factors such as prior knowledge or experiences which could affect their comprehension.

4) Limitations could also be that iPads could be costlier than books.

\section{Definition of Terms}

1) Reading Comprehensive-is the ability to read text, process it and understand its meaning (Moore, 2014). 
2) Ipads-electronic tablets used for reading books.

3) Developmental Reading Assessments (DRAs)-Developmental Reading Assessments (DRAs) are individually administered tests assessing a child's reading capabilities. They are tools used by instructors to identify students' reading levels, accuracy, fluency, and comprehension. Once levels are identified, an instructor can use this information for instructional planning purposes (Scholastics, 2015).

4) Quick Response (QR) Code-These codes can be read very quickly by a cell phone or other devices. They are used to take a piece of information from a transitory media and put it into other devices. They are more convenient and can store more data Including URL links, geo coordinates, and text (Lyne, 2009).

\section{Review of Related Literature}

The purpose of this action research study was to determine whether iPads were more effective than books in enhancing students' reading comprehension skills. In the following sections, I will discuss the positive effects that technology can have in the classroom, along with the negative effects that may be experienced as well. I will also discuss the different ways in which we can all look at technology that can help make it successful and become an asset to our students' educational process.

There is no doubt that technology has become a very important and life-changing factor in education. Classrooms have been modified to accommodate the use of technology such as SMART boards and iPads. These devices are currently taking the place of the original chalk boards, notebooks, and reading materials. Instead of using paper and a pencil to write the alphabets, students are now able to pick up an iPad and write using their finger while choosing from a variety of fonts and colors. Instead of choosing a textbook from the classroom library, students can simply scan a Quick Response (QR) code with their iPad and begin to read any book that is available with just a swipe of a finger. With all the money being invested in the use of technology in the classroom, it is important to know what exactly the benefits are in using these high-tech methods compared to the old-fashioned methods. Are there any differences in students' achievement when using technology compared to simply using materials that are not technical devices?

\section{Pros of Classroom Technology}

This section will look at the positive side of using iPads in the classroom. IPads can provide new and interesting ways to learn along with providing convenience in the classroom. According to Sadik (2008), using the technology of iPads does create more of a bond between teacher and students. Sadik (2008) states the findings from the study of digital storytelling proved that the students were engaged in authentic learning tasks and produced stories that revealed that they did well in projects and their stories met many of the pedagogical and technical 
attributes found in digital stories. Sadik (2008) says this showed that iPads could increase students' understanding of the story content they were reading. Robin \& Pierson (2005) state digital storytelling has been able to capture the imagination of both students and teachers. "Compared to conventional storytelling, digital storytelling audiences are viewed not only as listeners but also as learners who can interact and shape the story" (Dorner et al., 2002: p. 44). It has been found that digital storytelling can facilitate four student-centered strategies which include: student engagement, reflection for deep learning, project-based learning, and effective integration of technology into instruction (Robin \& Pierson, 2005). Hutchison, Beschorner, \& Schmidt-Crawford (2012: p. 23) back this up by saying "We found that using the iPads for literacy instruction not only supported student learning, but students were also highly engaged and able to demonstrate unique and creative ways of responding to text using a technology tool that offers some unique affordances to users."

According to Willis (2014), whether it is digital storytelling or just reading a story using an iPad; this method using technology tends to be more interesting and intriguing to students and teachers alike. Willis (2014) says that there are many pros to iPads which are: extended learning, vast library of resources, reduces printed materials and books; increases skills in science, technology, engineering, and math; engages students that are hard to reach, and helps prepare students for the workplace. Next, look at some of the possible drawbacks that could be experienced when using technology in the classroom.

\section{Cons of Classroom Technology}

While it is good to look at the positive side of anything, there will always be a few negative aspects that will also be present. When looking at the article from Sadik (2008), the idea that even though the use of iPads can be very exciting, some teachers are just not comfortable in using them in the classroom because they are not knowledgeable in how they work. Sadik (2008) says some teachers are set in the "old school" or more conventional type of instruction that they have been accustomed to for years. Although research emphasized the Importance of integrating iPads into the curriculum, the use of them can only be effective if teacher themselves possess the expertise to use them in a meaningful way in the classroom (Sadik, 2008: p. 488).

Another con would be occasional glitches that occur in iPads, but this is only a temporary problem that should not deter teachers from implementing it into their classroom (Sadik, 2008). The reading ability and the cultural and individual diversity issues of some students should also be considered when implementing iPads in the classroom to ensure that the needs of all diverse students are met (Sadik, 2008).

Finally, the expense of iPads needs to be considered and it is necessary to makesure that this extra expense can be justified by students receiving better instruction in the classroom (Sadik, 2008). Willis (2014) states that while there are 
many pros to using iPads, there are also some cons associated with their use such as: being broken by students, online safety and security issues, unnecessary distractions in the classroom, and the battery life. We all know that we can always turn a negative aspect into a positive one if we really try so let us look at some of the positive outlooks we can have when viewing the implementation of iPads in the classroom (Sadik, 2008).

\section{Positive Outlooks Concerning Technology}

For iPads to be successful in the classroom, "teachers must view it in a positive manner, be comfortable with it and use them effectively (Sadik, 2008: p. 497). According to Sadik (2008), there is a need to determine how teachers view the use of iPads while they are using them and when they have completed the process of using them. iPads should not be rejected just because they have not received enough instruction on them to know about all the useful functions they can perform (Sadik, 2008).

Sadik (2008) says teachers should look at the use of iPads as an improvement and learning experience that will not only benefit the student but them as well; by implementing positive and creativity in the classroom can make the difference between the success or failure of the teacher and their students. Teachers need to do all they can in order to incorporate every possible means of learning in the classroom so we can ensure our students receive all of the benefits of education they need in order to be successful in life; if the implementation of iPads can offer the benefits of improving reading comprehension, we should all be in favor of it (Sadik, 2008).

There are many reasons for having a positive outlook on the use of iPads and there has been much proof that to their effectiveness in the classroom. Looking through numerous articles that provide evidence, is one way that can be helpful to have a more positive attitude on the thought of incorporating iPads into the classroom.

James Harmon, who is an English teacher in Euclid, Ohio, conducted a teacher-research study so he could measure the effect of iPads on the language test scores of his students taking the annual Ohio graduation test. His findings indicated that "those students with iPad access in the year leading up to the test had a 6-percent greater chance of passing the test's reading portion than those without, and an 8-percent greater chance of passing the writing portion" (Saxena, 2014: p. 1). According to Saxena (2014), James Harmon said he also had more students completing the journal assignments on the iPads, compared to using notebooks the previous year and these results convinced him of the appropriateness of the iPad as a teaching tool, especially for improving the basic literacy skills of reading and writing. Saxena (2014) informs that there was also another study carried out by researchers at Örebro University in central Sweden, which found that when young children used tablets such as the iPads, they were better at writing than their counterparts who used pens and paper. The students 
were tested on both their reading comprehension and writing capabilities and it was found out that those using tablets were much more comfortable with the challenge (Saxena, 2014).

\section{Summary}

After reviewing the articles from Hutchison, Beschorner, \& Schmidt-Crawford (2012), Sadik (2008), Robinson \& Pierson (2005), Dorner (2002), and Willis (2014) about the pros and cons that is involved when implementing technology into the classroom; my research was focused on the use of Ipads in the classroom as an overview of how effective technology could be compared to some of the downfalls that can also be involved. I believe the research I did will show that the pros outweighed the cons and that technology proved to be very beneficial when comparing reading comprehension scores students using iPads compared to books. Northrop \& Killeen (2013: p. 536) state that "Apps offer a fun and motivational way for students to practice key early literacy concepts. They can be used during center time or independent seat work time and, with many programs, and can offer extended practice at home on parents' smart-phones. Apps should be used first with teacher guidance and feedback to ensure that students are correctly using and applying to the targeted literacy skill."

Ipads are just one of the technical devices used in my kindergarten classroom and they have been a very effective method for improving reading comprehension for my students this year. In this study, iPads are viewed in more depth to see how their use in the classroom impacts the improvement of reading comprehension in students. The positive side along with the downfalls of technology use will be viewed. It has been proven that things we do not know of can sometimes deter us from wanting to try them. This idea that some of us perceive affect the way we look at different things and unfortunately technology is one of them. Sometimes people are simply reluctant to try new things they are not accustomed to. It is important to look at diverse ways to flip the negatives into positives, so technology can have a chance to prove its value in the classroom. While there is much controversy on the use of technology, I believe the findings have helped to prove that overall technology is valuable in our classrooms and teachers and students will find it to be very beneficial in many ways once they get to know and understand technology better.

\section{Methodology}

I am teaching at a primary school in the Midwest during the school year 2015-2016. In my study, I focused on 10 kindergarten students that are in my classroom who participated. These 10 students were the only ones I received consent forms back from. There were five boys and five girls all from different socio-economic backgrounds. Nine students were Caucasian and one was half African American and Caucasian. All the students' first language was English. The study I conducted determined whether reading comprehension was im- 
proved when students were using iPads compared to reading from books. During reader's workshop, I called students up to the reading table independently and had the student read a book that was based on their reading level while assessing their reading using Developmental Reading Assessments (DRAs), which are individually administered tests that assess the reading capabilities of children. Developmental Reading Assessments (DRAs) are used by instructors to identify their students' reading level, accuracy, fluency, and comprehension. From the DRAs, students were asked to recall the events of the story they read from beginning, middle, and end with no or little prompting. During the first week, students read the stories selected based on their reading level using books. I assessed them at that time with DRAs. During week two, students chose another story corresponding with the reading level they had achieved at that time, but they read using the application of Raz-Kids on their iPads. Raz-Kids is a website where children can read books that are individualized to their reading level. After they read the story of their choice based on their reading level, I assessed the students' reading comprehension using the comprehension section of a DRA. The results from the comprehension section of the DRAs were then compared to see if the students' scores ranked the highest while reading from iPads compared to those reading from books.

\section{Research Design}

For the research design, I used the action research study to determine how technology affected learning in an early childhood classroom. The purpose of this study was to determine whether iPads in early childhood classrooms were beneficial in literacy and reading comprehension. I made the hypothesis that iPads would be much more effective than books in improving the reading comprehension scores of students. This method of study that I chose was a systematic way for teachers to be able to look at instructional practices that involve his/her students and it will help to find diverse ways to improve teacher effectiveness and student learning by problem-solving methods (Gay, Mills, \& Airasian, 2012).

During the first week, students individually read a story from books that were based on their reading level and then assessed using DRAs. During the second week, students individually read a story based on their reading level using the application Raz-Kids on their iPads and I assessed their reading comprehension using the comprehension section of a DRA. I am the only teacher in the class room, so these assessments were done during "Reader's Workshop". During this time, I called the individual child up to meet with me while the rest of the class was working in their assigned workstation. The purpose of these assessments was to see which method students would achieve the highest comprehension scores on. This information gave me an accurate figure as to which method scored the highest for reading comprehension in the classroom when comparing iPads to books. 


\section{Site of Study}

The research was conducted in a rural school district in the Midwest. This school district is made up of a diverse population of approximately 410 individuals which include students, staff, and faculty. The site of the study was my kindergarten classroom which provided the study with students from different socio-economic backgrounds, different genders, and different ethnicities. My classroom consists of nine girls and ten boys from different socio-economic backgrounds, for example, some of my students qualify for free school lunches and other programs while others make enough money to not qualify. Also, some students had parents or siblings who read with them at home while others came from a broken home or problematic home. Two students were from mixed races; Caucasian and African American. Every student in the classroom used English as their first language. It was important to take each of these factors into consideration when conducting a research study to compare results and conclude if any of these outlying factors could possibly affect results found from the study.

\section{Participants}

Since I was able to collect consent forms from 10 out of 19 students' families, 10 kindergarten students were finalized as participants of this study. There were five boys and five girls from different socio-economic backgrounds. There was one student who was African-American and the other nine were Caucasians. All the participants used English as the first language. Please see Table 1 below on demographics data of participants.

I obtained the demographic data included in this table based on the information I have available to me regarding my students such as the student's age, gender, ethnicity, and reading level. The information I have for the socio-economic status is a record of who is eligible to receive either free or reduced lunches, etc.

Table 1. Demographics data of participants.

\begin{tabular}{|c|c|c|c|c|c|}
\hline Participants & Age & Gender & Ethnicity & $\begin{array}{c}\text { Reading } \\
\text { Level }\end{array}$ & $\begin{array}{c}\text { Socio-Economic } \\
\text { Status }\end{array}$ \\
\hline Participant 1 & 6 & Male & Caucasian & 4 & Middle Class \\
\hline Participant 2 & 6 & Male & $\begin{array}{c}\text { African } \\
\text { American/Caucasian }\end{array}$ & 8 & Low Class \\
\hline Participant 3 & 6 & Female & Caucasian & 8 & Middle Class \\
\hline Participant 4 & 6 & Female & Caucasian & 5 & Middle Class \\
\hline Participant 5 & 6 & Female & Caucasian & 5 & Low Class \\
\hline Participant 6 & 6 & Female & Caucasian & 6 & Upper Class \\
\hline Participant 7 & 6 & Female & Caucasian & 6 & Middle Class \\
\hline Participant 8 & 6 & Male & Caucasian & 8 & Middle Class \\
\hline Participant 9 & 6 & Male & Caucasian & 6 & Low Class \\
\hline Participant 10 & 6 & Male & Caucasian & 8 & Upper Class \\
\hline
\end{tabular}




\section{Ethical Considerations}

The first step I took was to contact the Missouri State University Institutional Review Board (IRB), and I submitted a proposal to the chair of the board to make sure that I got the approval forms I needed so there were not any problems with the type of research I was conducting that might jeopardize the welfare of my students. The rights of the participants were protected by sending home a permission slip detailing what the action research consisted of and I got a signed form of consent from the kindergarten students' legal guardians.

\section{Data Collection Procedures}

Ten students participated in my study of iPads Versus Books. I had them come up individually to select a story of interest based on their reading level. On week one of the study, students read a story from a book while I administered the DRAs. On week two of the study, students read a similar story from the application Raz-Kids using iPads. They were assessed at the end of the story using the comprehension section of a DRA. The test scores from the reading comprehension section of the DRAs were compared to find out if reading from iPads resulted in higher comprehension scores than books. Since I am the only teacher in the classroom, I administered the DRAs during "Readers Workshop", a time where students work with a partner in an assigned workstation that was self-regulated with little or no assistance.

\section{Instrumentation}

I used DRAs to record the participants' reading comprehension scores after the participants had read the selected stories based on their reading level from books and then similar stories from iPads (See Appendix for information on DRAs).

\section{Role of the Researcher}

My role in this action research was the kindergarten teacher and main facilitator. I chose my participants, carried out the research, and documented my findings along with comparing my data when the research was complete. My position on this study was that I believed students were more engaged in reading when using iPads compared to using books. I observed my kindergarten students when they used iPads and books and they seemed to be a lot more interested in the stories they were reading when using the iPads. I also noticed they seemed to answer a lot more questions that they were asked when using iPads too. Children seem to hold a lot of interest in electronic devices these days because they are new ways of learning and this fascinates them. These devices seem to make reading more convenient. My findings in this study were that when the students tested after reading from the iPads, they scored higher than when they tested after reading from books. This hypothesis is being made from the research I have done and from the positive experience with the students in my classroom when using creative methods to provide instructions. The use of technology in the classroom 
seemed to get the attention of the students and I believe technology, whether using iPads, SMART boards, or computers fulfills both the creativity needed to assist students in learning and successfully engages them in the classrooms.

\section{Data Analysis}

This study compared the data collected from the 10 participants using books and iPads. I documented the students' scores from the comprehension section of the DRAs when reading from books and from iPads. I then documented which method had the highest scores, proving by hypothesis that students achieved higher comprehension scores when reading from iPads compared to reading from books.

\section{Study Results}

The nature of this study was to find out if students' reading comprehension was higher when reading from books or iPads, or if there was any relationship at all. I used comprehension scores from DRAs to assess the students when reading from books and when reading from iPad using the application Raz-Kids. The comprehension section of the DRA consisted of seven subcategories which were added together to come up with the final reading comprehension scores when reading from books and iPads. The subcategories were: previewing, the retelling the sequence of events, retelling of characters and details, retelling using vocabulary in the text, retelling with teacher support, reflection and making connections to the story. After the participant was finished reading, I would close the book or turn off the iPad and ask the participant to start from the beginning of the story and tell me what happened in the story. I would record the participant's response hoping for a clear beginning, middle, and end of the story. If I needed more information from the student, I would prompt them as little as possible by asking questions such as "What else happened?" or "Tell me more". After the participant retold the story to the best of his or her knowledge, I asked the participant which part he or she liked best and why. I then followed up by asking the participant what this story made him or her think of or what connection he or she made with the story.

Based on the study, I feel that my hypothesis was correct in that students did receive higher scores on reading comprehension when reading from iPads compared to reading from books. Since the participants ranged from different genders, ethnicities, socio-economic statuses, and reading levels, I do not feel that any of these things were a factor in the results of this study due to every participant either scored the same or higher in reading comprehension when reading from iPads.

In Table 2, I am including the subcategories and examples of how these categories are scored. I have also added examples in this table to clarify the information of what students are scored on when being assessed.

Below is an example of the rubric from the comprehension section of the 
Table 2. Rubric for subcategories.

The participant is able to identify and connect
events in the story when previewing the story.
(e.g., student is able to tell what is going on
in the story by looking at the pictures)
Participant is able to retell the important events of the
story including beginning, middle, and end.
(e.g., student tells the story in sequential order)
The participant can refer to the actual characters
in the story and important events.
(e.g., Tommy went to the park with Joseph)
Participant retells the story using the
vocabulary used in the story.
(e.g., The big bad wolf huffed and puffed
and blew the pig's house down)
Participant can retell the story with little or
no teacher support.
Retelling: Teacher Support $\quad$ (e.g., student is able to tell the story without the teacher
asking, "What happened next?" or "Tell me more?")
Participant makes a high-level thinking
inference about the story.
Making Connections $\quad$ Participant makes a thoughtful connection to the story
(e.g., "This story made me think of the time I went to the
park with my friend...")

DRA. In Table 3, I broke down each score by their subcategory and entered the scores that participants could receive.

In Table 4, I broke down each score by their subcategory and entered the scores received when students were reading from books and iPads. The point scale is one to four with one being the lowest to four being the highest points that can be scored on the evaluation.

In Table 5, I included the total of the final scores of each participant and the story they read from both books and iPads. The scores shown in the chart below were based out of a total of 28 points possible.

The bar in Figure 1 shows the scores from students when reading from books versus when they were reading from iPads. Participant two was the only one who scored the same for both books and iPads. The rest of my students scored higher when reading from iPads compared to reading from books.

\section{Discussion}

With a lot of focuses shifting to technology in classrooms and beginning the use and instruction of use of technology as early as preschool, it is important to know and understand the benefits that devices such as iPads bring to the classroom. There is no doubt that my students love using iPads in the classroom and they are engaged for long periods of time on the iPads. The study I conducted on 
Table 3. DRA comprehension rubric.

\begin{tabular}{|c|c|c|c|c|}
\hline Previewing & $\begin{array}{l}\text { 1) Comments } \\
\text { briefly about } \\
\text { each event or } \\
\text { action only } \\
\text { when prompted } \\
\text { or is uncertain }\end{array}$ & $\begin{array}{l}\text { 2) Identifies and } \\
\text { comments briefly } \\
\text { about each event } \\
\text { or action with } \\
\text { some prompting }\end{array}$ & $\begin{array}{l}\text { 3) Identifies and } \\
\text { connects at least } \\
\text { three key events } \\
\text { without } \\
\text { prompting; some } \\
\text { relevant } \\
\text { vocabulary }\end{array}$ & $\begin{array}{l}\text { 4) Identifies and } \\
\text { connects at least } \\
\text { four key events } \\
\text { without } \\
\text { prompting; } \\
\text { relevant } \\
\text { vocabulary }\end{array}$ \\
\hline $\begin{array}{l}\text { Retelling: } \\
\text { Sequence of } \\
\text { Events }\end{array}$ & $\begin{array}{l}\text { 1) Includes only } \\
\text { one or two } \\
\text { events or details } \\
\text { (limited } \\
\text { retelling) }\end{array}$ & $\begin{array}{l}\text { 2) Includes at least } \\
\text { three events } \\
\text { generally in } \\
\text { random order } \\
\text { (partial retelling) }\end{array}$ & $\begin{array}{l}\text { 3) Includes most } \\
\text { of the notable } \\
\text { events from the } \\
\text { beginning, middle, } \\
\text { and end generally } \\
\text { in sequence }\end{array}$ & $\begin{array}{l}\text { 4) Includes all } \\
\text { notable events } \\
\text { from the } \\
\text { beginning, } \\
\text { middle, and end } \\
\text { in sequence }\end{array}$ \\
\hline $\begin{array}{l}\text { Retelling: } \\
\text { Characters } \\
\text { and Details }\end{array}$ & $\begin{array}{l}\text { 1) Refers to } \\
\text { characters } \\
\text { using general } \\
\text { pronouns; may } \\
\text { include } \\
\text { incorrect } \\
\text { information }\end{array}$ & $\begin{array}{l}\text { 2) Refers to } \\
\text { characters using } \\
\text { appropriate } \\
\text { pronouns; } \\
\text { includes, at least, } \\
\text { one detail; may } \\
\text { include some } \\
\text { misinterpretation }\end{array}$ & $\begin{array}{l}\text { 3) Refers to most } \\
\text { characters by } \\
\text { name and includes } \\
\text { some vital details }\end{array}$ & $\begin{array}{l}\text { 4) Refers to all } \\
\text { characters by } \\
\text { name and } \\
\text { includes most of } \\
\text { the important } \\
\text { details }\end{array}$ \\
\hline $\begin{array}{l}\text { Retelling: } \\
\text { Vocabulary }\end{array}$ & $\begin{array}{l}\text { 1) Uses general } \\
\text { terms or labels; } \\
\text { limited } \\
\text { understanding } \\
\text { of keywords/ } \\
\text { concepts }\end{array}$ & $\begin{array}{l}\text { 2) Uses some } \\
\text { language/ } \\
\text { vocabulary from } \\
\text { the text; some } \\
\text { understanding } \\
\text { of keywords/ } \\
\text { concepts }\end{array}$ & $\begin{array}{c}\text { 3) Uses } \\
\text { language/ } \\
\text { vocabulary from } \\
\text { the text; basic } \\
\text { understanding of } \\
\text { most keywords/ } \\
\text { concepts }\end{array}$ & $\begin{array}{l}\text { 4) Uses } \\
\text { important } \\
\text { language/ } \\
\text { vocabulary from } \\
\text { the text; good } \\
\text { understanding of } \\
\text { keywords/ } \\
\text { concepts }\end{array}$ \\
\hline $\begin{array}{l}\text { Retelling: } \\
\text { Teacher } \\
\text { Support }\end{array}$ & $\begin{array}{l}\text { 1) Retells with } \\
\text { five or more } \\
\text { questions or } \\
\text { prompts }\end{array}$ & $\begin{array}{l}\text { 2) Retells with } \\
\text { three or four } \\
\text { questions or } \\
\text { prompts }\end{array}$ & $\begin{array}{l}\text { 3) Retells with one } \\
\text { or two questions } \\
\text { or prompts }\end{array}$ & $\begin{array}{l}\text { 4) Retells with no } \\
\text { questions or } \\
\text { prompts }\end{array}$ \\
\hline Reflections & $\begin{array}{l}\text { 1) Gives an } \\
\text { unrelated } \\
\text { response, no } \\
\text { reason for } \\
\text { opinion or no } \\
\text { response }\end{array}$ & $\begin{array}{l}\text { 2) Gives a limited } \\
\text { response and/or a } \\
\text { general reason for } \\
\quad \text { opinion }\end{array}$ & $\begin{array}{l}\text { 3) Gives a specific } \\
\text { story event/action } \\
\text { and a relevant } \\
\text { reason for } \\
\text { response (e.g. } \\
\text { personal } \\
\text { connection). }\end{array}$ & $\begin{array}{l}\text { 4) Gives a } \\
\text { response and } \\
\text { reason that } \\
\text { reflects higher } \\
\text { level thinking } \\
\text { (e.g. synthesis/ } \\
\text { inference) }\end{array}$ \\
\hline $\begin{array}{l}\text { Making } \\
\text { Connec- } \\
\text { tions }\end{array}$ & $\begin{array}{l}\text { 1) Makes an } \\
\text { unrelated } \\
\text { connection, } \\
\text { relates an event } \\
\text { in the story or } \\
\text { gives no } \\
\text { response }\end{array}$ & $\begin{array}{l}\text { 2) Makes a } \\
\text { connection that } \\
\text { reflects a limited } \\
\text { understanding of } \\
\text { the story }\end{array}$ & $\begin{array}{l}\text { 3) Makes a literal } \\
\text { connection that } \\
\text { reflects a basic } \\
\text { understanding of } \\
\text { the story }\end{array}$ & $\begin{array}{l}\text { 4) Makes a } \\
\text { thoughtful } \\
\text { connection that } \\
\text { reflects a deeper } \\
\text { understanding of } \\
\text { the story }\end{array}$ \\
\hline Score & $\begin{array}{rrr}78 & 9 & 10 \\
11 & 12 & 13\end{array}$ & 1415161718 & $\begin{array}{c}19202122 \\
232425\end{array}$ & 262728 \\
\hline
\end{tabular}


Table 4. Scores when reading from books and IPads (1 to 4 points scale).

\begin{tabular}{|c|c|c|c|c|c|c|c|c|}
\hline Participant & Device & Pre-viewing & $\begin{array}{l}\text { Retelling: } \\
\text { Sequence of } \\
\text { Events }\end{array}$ & $\begin{array}{c}\text { Retelling: } \\
\text { Characters and } \\
\text { Details }\end{array}$ & $\begin{array}{l}\text { Retelling: } \\
\text { Vocabulary }\end{array}$ & $\begin{array}{c}\text { Retelling: } \\
\text { Teacher Support }\end{array}$ & Reflection & $\begin{array}{c}\text { Making } \\
\text { Connections }\end{array}$ \\
\hline \multirow{2}{*}{1} & Book & $3 / 4$ & $2 / 4$ & $3 / 4$ & $3 / 4$ & $2 / 4$ & $2 / 4$ & $2 / 4$ \\
\hline & IPad & $3 / 4$ & $3 / 4$ & $3 / 4$ & $4 / 4$ & $3 / 4$ & $4 / 4$ & $3 / 4$ \\
\hline \multirow{2}{*}{2} & Book & $4 / 4$ & $4 / 4$ & $4 / 4$ & $4 / 4$ & $4 / 4$ & $3 / 4$ & $3 / 4$ \\
\hline & IPad & $4 / 4$ & $4 / 4$ & $4 / 4$ & $4 / 4$ & $4 / 4$ & $4 / 4$ & $3 / 4$ \\
\hline \multirow{2}{*}{3} & Book & $4 / 4$ & $3 / 4$ & $2 / 4$ & $3 / 4$ & $3 / 4$ & $3 / 4$ & $3 / 4$ \\
\hline & IPad & $4 / 4$ & $4 / 4$ & $4 / 4$ & $4 / 4$ & $3 / 4$ & $4 / 4$ & $4 / 4$ \\
\hline \multirow{2}{*}{4} & Book & $4 / 4$ & $4 / 4$ & $3 / 4$ & $3 / 4$ & $4 / 4$ & $3 / 4$ & $2 / 4$ \\
\hline & IPad & $4 / 4$ & $4 / 4$ & $4 / 4$ & $4 / 4$ & $4 / 4$ & $4 / 4$ & $3 / 4$ \\
\hline \multirow{2}{*}{5} & Book & $4 / 4$ & $3 / 4$ & $3 / 4$ & $3 / 4$ & $3 / 4$ & $3 / 4$ & $1 / 4$ \\
\hline & IPad & $4 / 4$ & $4 / 4$ & $4 / 4$ & $4 / 4$ & $3 / 4$ & $3 / 4$ & $4 / 4$ \\
\hline \multirow{2}{*}{6} & Book & $4 / 4$ & $3 / 4$ & $3 / 4$ & $3 / 4$ & $3 / 4$ & $4 / 4$ & $4 / 4$ \\
\hline & IPad & $4 / 4$ & $3 / 4$ & $4 / 4$ & $4 / 4$ & $3 / 4$ & $3 / 4$ & $4 / 4$ \\
\hline \multirow{2}{*}{7} & Book & $3 / 4$ & $1 / 4$ & $3 / 4$ & $3 / 4$ & $4 / 4$ & $3 / 4$ & $1 / 4$ \\
\hline & IPad & $3 / 4$ & $4 / 4$ & $4 / 4$ & $4 / 4$ & $3 / 4$ & $4 / 4$ & $4 / 4$ \\
\hline \multirow{2}{*}{8} & Book & $2 / 4$ & $1 / 4$ & $2 / 4$ & $2 / 4$ & $1 / 4$ & $2 / 4$ & $2 / 4$ \\
\hline & IPad & $4 / 4$ & $4 / 4$ & $3 / 4$ & $4 / 4$ & $4 / 4$ & $4 / 4$ & $4 / 4$ \\
\hline \multirow{2}{*}{9} & Book & $2 / 4$ & $2 / 4$ & $3 / 4$ & $3 / 4$ & $3 / 4$ & $3 / 4$ & $3 / 4$ \\
\hline & IPad & $4 / 4$ & $3 / 4$ & $2 / 4$ & $4 / 4$ & $3 / 4$ & $1 / 4$ & $3 / 4$ \\
\hline \multirow{2}{*}{10} & Book & $3 / 4$ & $2 / 4$ & $3 / 4$ & $4 / 4$ & $3 / 4$ & $3 / 4$ & $3 / 4$ \\
\hline & IPad & $4 / 4$ & $4 / 4$ & $4 / 4$ & $4 / 4$ & $3 / 4$ & $4 / 4$ & $4 / 4$ \\
\hline
\end{tabular}

Table 5. Final DRA comprehension scores from books versus ipads.

\begin{tabular}{|c|c|c|}
\hline Participants & Scores From Books & Scores From Ipads \\
\hline Participant 1 & $\begin{array}{c}\text { "Where Is My Hat?" } \\
17 / 28\end{array}$ & $\begin{array}{c}\text { "What Is At the Zoo?" } \\
23 / 28\end{array}$ \\
\hline Participant 2 & $\begin{array}{l}\text { "Duke" } \\
26 / 28\end{array}$ & $\begin{array}{c}\text { "At the Rodeo" } \\
26 / 28\end{array}$ \\
\hline Participant 3 & $\begin{array}{l}\text { "Duke" } \\
21 / 28\end{array}$ & $\begin{array}{c}\text { "Where Plants Grow" } \\
26 / 28\end{array}$ \\
\hline Participant 4 & $\begin{array}{l}\text { "Where Is My Hat?" } \\
23 / 28\end{array}$ & $\begin{array}{l}\text { “Get In" } \\
27 / 28\end{array}$ \\
\hline Participant 5 & $\begin{array}{l}\text { "Where Is My Hat?" } \\
20 / 28\end{array}$ & $\begin{array}{l}\text { “Get In” } \\
26 / 28\end{array}$ \\
\hline Participant 6 & $\begin{array}{c}\text { "Why Are We Stopping?" } \\
24 / 28\end{array}$ & $\begin{array}{l}\text { "Allie and Ollie" } \\
25 / 28\end{array}$ \\
\hline Participant 7 & $\begin{array}{c}\text { "Why Are We Stopping?" } \\
18 / 28\end{array}$ & $\begin{array}{l}\text { "Allie and Ollie" } \\
26 / 28\end{array}$ \\
\hline Participant 8 & $\begin{array}{l}\text { "Duke" } \\
12 / 28\end{array}$ & $\begin{array}{c}\text { "Community Helpers" } \\
27 / 28\end{array}$ \\
\hline Participant 9 & $\begin{array}{c}\text { "Why Are We Stopping?" } \\
19 / 28\end{array}$ & $\begin{array}{c}\text { "At the Zoo" } \\
20 / 28\end{array}$ \\
\hline Participant 10 & $\begin{array}{l}\text { "Duke" } \\
21 / 28\end{array}$ & $\begin{array}{l}\text { “Get In" } \\
27 / 28\end{array}$ \\
\hline
\end{tabular}




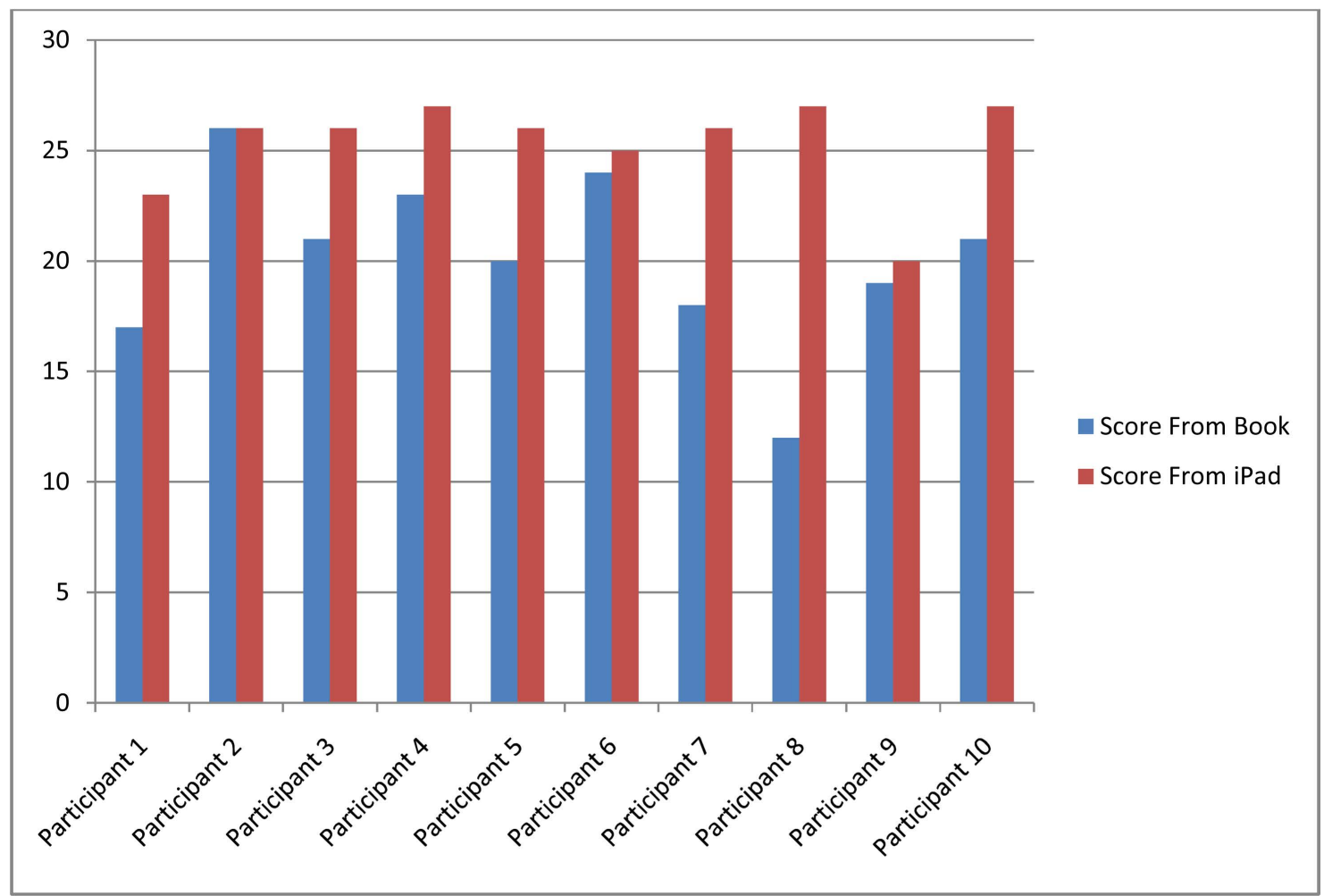

Figure 1. Results from books versus IPads.

the 10 students in my classroom shows that 9 out of 10 students scored higher in reading comprehension when reading using iPads compared to reading from books. The importance of this study was to provide proof that iPads would be beneficial in the classroom and it also proved that students scored higher on reading comprehension which inferred that they better comprehended the material they were reading when using iPads versus books. This is important when teaching literacy. Students need to be able to comprehend the material that they are reading and not just go through the actions of reading. This will instill a love of reading in children at an early age which is important for them academically.

Although the findings of this study clearly indicated that participants scored higher on reading comprehension scores when reading from an iPad, there are several limitations of this study. A challenge in this study was that there were no DRAs for stories on the iPads available, so I used the comprehension section of a DRA and developed questions using the same categories and patterns to assess the students' comprehension when reading from the iPad using the Raz-Kid's application. This could have caused a difference in how the child interpreted the questions during each part of the study resulting in an answer with a higher score. Another limitation would include the variety of books to choose from. There are only two books to choose from in each reading level of the DRA when reading from a book compared to several that were available from the application "Raz-Kids". This could have resulted in the child having a higher interest or prior knowledge on a certain topic. 
This study was limited to a small scale of participants due to only receiving a small number of consent forms back from the students' parents. In the future, educational research should continue to focus on the use of iPads in the classroom. The research should increase to build awareness of the benefits and uses of iPads in the classroom. Larger scale and longitudinal data collection across schools with various demographics of participants would allow for more accurate results. Students and teachers can benefit from using iPads in the classroom.

The ability to obtain higher reading comprehension scores using applications such as Raz-Kids on the iPad, allow for student achievement and growth. This method is also child-friendly and does not have to be administered by a teacher; therefore, this frees up time for educators to focus on students who may need more one-on-one assistance. The ability to promote the benefits and effectiveness of iPads in the classroom will allow future educators and students to implement the use of iPads in their classroom and reap the benefits in which they provide.

\section{References}

CCSD (2015). Developmental Reading Assessment (DRA). Charleston County School District.

Dorner, R., Grimm, P., \& Abawi, D. (2002). Synergies between Interactive Training Simulations and Digital Storytelling: A Component-Based Framework. Computers \& Graphics, 26, 45-55. https://doi.org/10.1016/S0097-8493(01)00177-7

Gay, L., Mills, G., \& Airasian, P. (2012). Educational Research. Competencies for Analysis Applications (10th ed., pp. 507-508). London: Pearson Education, Inc.

Goodman, Y. (1986). Coming to Know Literacy. In W. Teale, \& E. Sulzby (Eds.), Emergent Literacy: Writing and Reading (pp. 1-14). New York, NY: Ablex Publishing.

Hutchison, A., Beschorner, B., \& Schmidt-Crawford, D. (2012). Exploring the Use of the iPad for Literacy Learning. Reading Teachers, 66, 15-23. https://doi.org/10.1002/TRTR.01090

Labbo, L. (1996). A Semiotic Analysis of Children's Symbol Making in a Classroom Computer Center. Reading Research Quarterly, 31, 356-385. https://doi.org/10.1598/RRQ.31.4.2

Leonard, D. (2013). The iPad Goes to School. New York, NY: Bloomberg Company. http://www.bloomberg.com/bw/articles/2013-10-24/the-ipad-goes-to-school-the-rise-o f-educational-tablets

Lyne, M. (2009). What Is a QR Code and Why Do You Need One? Redding, CT: Third Door Media, Inc. http://searchengineland.com/what-is-a-qr-code-and-why-do-you-need-one-27588

Moore, A. (2014). Train the Brain. Get Smarter. LearningRx, Inc. http://www.learningrx.com/reading-comprehension-skills.html

Northrop, L., \& Killeen, E. (2013). A Framework for Using iPads to Build Early Literacy Skills. Reading Teacher, 66, 531-537.

Razkids (2015). Houghton Mifflin Harcourt. https://www.raz-kids.com

Robinson, B., \& Pierson, M. (2005). A Multilevel Approach to Using Digital Storytelling in the Classroom. Houston, TX: University of Houston. http://www.coe.uh.edu/digital-storytelling/course/SITE2005 
Sadik, A. (2008). Digital Story Telling: A Meaningful Technology-Integrated Approach for Engaged Student Learning. Education Tech Research Development, 55, 488-503.

Saxena, S. (2014). Improving Reading and Writing Using iPads. EdTechReview. http://edtechreview.in/trends-insights/insights/942-improving-reading-and-writing-usi $\underline{\text { ng-ipads }}$

Scholastics (2015). Assess DRA Reading Levels. New York, NY: Scholastics, Inc. http://www.scholastic.com/parents/resources/article/book-selection-tips/assess-dra-rea ding-levels

Subramanian, C. (2012). New Studies Find iPads in the Classroom Boost Test Scores. New York, NY: Time, Inc.

http://techland.time.com/2012/02/22/new-study-finds-ipads-in-the-classroom-boost-te st-scores/

Willis, J. (2014). The Pros and Cons of Using Tablets in the Classroom. Westwoneducation.co.

https://pidp31002015kv.files.wordpress.com/2015/01/the-pros-and-cons-of-using-table ts-in-the-classroom-_-westwon.pdf 


\section{Appendix}

\section{Appendix. Information on DRA's}

\section{CCSD (2015)}

Developmental Reading Assessment (DRA2)

1) What is the DRA?

The Developmental Reading Assessment provides teachers with a method for assessing and documenting primary students' development as readers over time. Its purpose is to identify students' reading level, defined as a text on which students meet specific criteria in terms of accuracy, fluency, and comprehension. Additional purposes include identifying students' independent reading strengths and weaknesses, planning for instruction, monitoring reading growth, and, for the grades 3 - 5, preparing students to meet classroom testing expectations and providing information to teachers, schools, and region regarding reading achievement. The assessments are conducted during one-on-one reading conferences as children read specially selected assessment texts. A set of leveled texts, which increase in difficulty, are used for the assessment. The DRA evaluates the major aspects of reading that are critical to independence as a reader.

2) What is the DRA Word Analysis?

The DRA Word Analysis is designed to evaluate the phonological awareness and phonics skills of students in kindergarten and early first grade and the word analysis skills of below-grade-level readers in Grades 1 - 5 .

3) How do I administer the DRA?

The DRA should be administered on a semiannual basis or more frequently in the case of struggling readers. Teachers should administer the assessment to their own students to provide them with information on which to base their teaching practices. Assessment should take place in a part of the room that allows for one-on-one observation and conversation without distractions or interruptions. Other students should not overhear the stories being read aloud or retold. The assessment should take place in one sitting. Don't break off in the middle of an assessment. If it appears that the student will need further assessment, you should continue on another day. Set yourself up in a quiet area with texts and observation sheets where other students cannot hear the conversation.

Try to assess at least 1 or 2 students each day during an independent work time. This creates minimal disruption to the class and allows the teacher to fill out the forms while the reading behaviors of the child are fresh in his/her memory.

Explain to students that you will be sitting down to read with everyone so you can get to know what they have learned about reading. Telling students they are being tested only creates stress!

4) Overview

For levels A to 2

$\checkmark$ Teacher selects the text

$\checkmark$ Teacher introduces the text 
Teacher reads one or two pages

$\checkmark$ Child points and reads the rest of the story; teacher takes running record of oral reading

For Levels 3 to 12

$\checkmark$ Teacher or student selects the text that seems just right for him or her

$\checkmark$ Teacher introduces the text

$\checkmark$ Student reads complete text aloud; teacher takes running record of oral reading

$\checkmark$ Student retells either the story or the information read to demonstrate comprehension

For Levels 14 to 24

$\checkmark$ Teacher selects a range of three texts

$\checkmark$ Student chooses one that seems just right

$\checkmark$ Teacher introduces the text

$\checkmark$ Student reads the first two to four paragraphs or pages aloud; teacher takes a running record of oral reading and records time

$\checkmark$ Student reads remaining text silently in another location

$\checkmark$ Student retells story or shares information gained from text

For Levels 28 and above

$\checkmark$ Teacher selects a range of three texts

$\checkmark$ Student chooses one that seems just right

$\checkmark$ Teacher introduces the text

$\checkmark$ Student reads the first two to four paragraphs or pages aloud; teacher takes a running record of oral reading and records time

$\checkmark$ Student reads remaining text silently in another location

$\checkmark$ Student respond in writing to questions and prompts in the student booklet

5) Before the Assessment

- Duplicate the black line masters from the CD of the levels needed. Running records will be recorded on the out loud reading of books/passages. Plan on a minimum of one for each student.

- Stopwatch or watch with second-hand.

- Become familiar with the stories the students will be reading.

6) Introduction

- Choose a level that is a good estimate of where a student is able to be successful. If a student struggles, $\underline{\text { STOP}}$, go back to an easier level, or say, "This isn't a very good book to read today. You go back to your seat now and I'll look for a better one to read another time." Be careful to not let frustration set in at the onset of this assessment.

- In Levels 18 - 44, you will ask the student to read aloud the first few paragraphs to determine if you have selected an appropriate text.

- The converse is also true. If a student easily reads the level with few or no errors in a short amount of time, then it would be appropriate to have the student move up to a higher level. It is not required to have each level read. Once the appropriate level has been established, proceed with the steps to 
give the assessment.

- Introduce the book by reading the first script on the Observation sheet.

- This is a time to also let the student know that they will be retelling the story to you from beginning to end. They will have a chance to re-read the story silently before they begin the retell.

\section{Introducing the Text}

Sample introduction: "I am going to ask you to read a story aloud to me. Read it as best you can. I can't help you; so if you come to a word you don't know, just try your best. I'm going to take some notes while you're reading so I can remember what you say." Allow the student to take a "picture walk" through the text. There is no time limit for this. The student may want to tell you a story based on the illustrations and this is allowed.

Teacher may continue with: "The story you are going to read is called (Supply the title). It is about ." (Supply one line plot summary provided.) This is a time to also let the student know that they will be retelling the story to you from beginning to end. They will have a chance to re read the story silently before they begin the retell.

\section{During the Assessment}

- Start the timing as soon as the child begins to read.

- An accurate note of minutes and seconds must be made when the reading stops.

- Once the oral reading is over, the student should take the book and read it again silently. This gives them another opportunity to check themselves on comprehension before the retelling. During this time the teacher should mark the score for phrasing based on the rubric on the Student Information Sheet.

- Once the student has finished reading the book or portion silently, the teacher may prompt the retelling with "Think back to the beginning, and tell me the story. Tell me everything you remember about it." If the retelling seems incomplete, the teacher should prompt with, "Tell me more." This prompt should be used only once. Or start the first section of the student booklet.

- When the student finishes the retelling, the teacher should score that skill before seeing another student based on the rubric on the Student Information Sheet.

\section{After the Assessment}

- Add up all the scores for accuracy, fluency rate, phrasing and retelling will indicate the strength or weakness of the student at that level.

- Analyze the Data - In performance-based assessments, it is important to move beyond just the score and look at what strategies and or skills the student used effectively, used ineffectively or neglected. Certain questions can be explored.

- Did the error make sense?

- Did the student use meaning when the error was made?

- Noticed an error and reread

- Attempted self-correction

- Used picture clues to attempt words

Read something sensible, even if it didn't match letter sounds of the correct word

Skips word or reads ahead

Inserted extra words which supported the meaning

- Are there any visual similarities between the error and the actual text?

Did the student look through the word for known parts or endings?

Substituted a word that started with the same sound as the correct word.

Appears to "sound out the word"

Covers ending or prefix

Gets beginning or ending sounds correct although the word is wrong

Made a sound for each letter in the word

What does the student do at difficulty? Stop? Reread? Appeal for help?

- Plan Teaching - With this type of assessment, it can become an integral part of the teacher's ongoing instruction, providing them with strategies to understand students' early reading performance. This assessment also helps the teacher identify and document change over time. 


\section{7) Oral Reading}

- Take a running record of oral reading for all Levels.

- Ticking each correct word is not necessary and allows the recorder to note other behaviors more accurately.

- Appeals are noted (A); they are scored as errors ONLY if the word is told to the student $(\mathrm{T})$. The only acceptable prompt is "try something". The prompt is given after about a 5 second wait. Wait again. Tell the word if necessary ( $\mathrm{T}$ ). (A wait with a questioning look or tone can be considered an appeal. This prompt does not count as an error).

- Other prompts such as "Look at the first letter" or "Look at the picture" are absolutely not admissible.

- Use standard conventions for recording so others can refer to the record and "read" it accurately (See laminated sheet).

- Record self corrections. Be watchful, however, for students who make many, many errors, constantly_self-correcting. This behavior clearly interferes with fluency.

8) Fluency

The total number of oral reading errors is converted to an accuracy score. Beginning at level 14, oral reading is timed, using a words-per-minute (WCPM) metric. Three to four aspects of oral reading are rated on a 4-point scale: expression, phrasing, rate, and accuracy.

9) Comprehension

- In Levels 3 - 16, once the oral reading is over, the student should take the book and read it again silently. This gives them another opportunity to check themselves on comprehension for retelling. Then, you will close the book and tell the student to, "Start at the beginning and tell me what happened in the story."

- Underline information that the student is able to give, but which requires prompting.

- Note information that the student is able to give, but which requires prompting, with a TP (teacher prompt).

- Follow-up questions follow the summary and if used need to be tallied to the left. The number of prompts to elicit more information will be calculated as part of the comprehension score.

- Try to use only the follow-up questions provided, but if you need to ask others, be sure to record them in the space provided. All information provided by the child (both prompted and unprompted) is considered valid information when determining the comprehension score.

10) Using the Comprehension Rubric-To pass a level a student should score in the Adequate (16 - 24) range.

In the early levels (A-6) there is very little substance to the stories: little to retell that is not apparent from the pictures, few events and characters and very little room for misinterpretation. Therefore, this rubric does not work well, and 
retelling at these levels is not necessary for the average student except to build the understanding that this is something we need to learn how to do.

In levels 8-16 the rubric works better; however, some stories have only 2 characters, characters may not be given names, and the stories do not lend themselves to inferential thinking.

The general rule when scoring the rubric at these levels is to NOT penalize the student for information that is not in the story (i.e., if there are only 2 characters and the student mentions 3 in the retelling, score a 3 or 4 ).

11) Overall Tips

- Readings are administered only as far as the student is able to read with:

- At least $90 \%$ accuracy (Levels A-1)

o At least $91 \%$ accuracy (Level 2)

o At least $94 \%$ accuracy (Levels 3 - 44)

- Adequate comprehension (see DRA Observation Guide sheets)

- Make notes about reading behaviors and strategies for future reference.

- Stop once a student falls into the Instructional or Independent level and information is gained that would drive instruction for that student to progress as a reader.

12) Questions

What if a student is successful at passing a level beyond their grade level?

The student should be retested to verify that the information on the last assessment is correct. It is highly recommended that students reaching Level 44 have an independent score for fluency and comprehension before they are considered proficient at this level. If a student reads several levels above grade level, speak with your site literacy specialist for recommendations for this issue.

What is the difference between independent and instructional levels?

The 90 - 94 percent range represents the student's instructional level, and it is the instructional level that should be reported. A student's independent level is the level at which he/she reads with $95-100$ percent accuracy, with fluency, and comprehension. A student's independent level is generally one or two levels lower than his/her instructional level.

Can I use the DRA for monthly monitoring of students' independent reading level?

The DRA is not an appropriate tool to use for the monthly monitoring of students' independent reading level. This leads to over-use of the DRA and students will eventually learn the test. Teachers can use a running record with leveled/benchmark books for monthly monitoring.

Can I share this information with parents?

Yes! Parent Teacher Conferences are an excellent time to share this information with parents. Share results. It is important for this to be an informing, yet hopeful encounter. It may be helpful to provide a copy of the level book that the student read. This is an opportunity for the parents and the teacher to form a partnership focusing on the support of their child's progress. Some strategies 
you might suggest to parents are:

$\checkmark$ Read with child daily.

$\checkmark$ Talk about reading strategies.

$\checkmark$ Talk about the story, highlighting main points.

$\checkmark$ Practice high frequency words.

$\checkmark$ Listen to books on tape.

$\checkmark$ Tape the child while reading and have them listen to it.

Adults can provide a role model for daily reading with book, newspapers, and magazines. 